\title{
UPOREDNA ANALIZA STARTAP EKOSISTEMA REPUBLIKE SRBIJE I DRŽAVA JUGOISTOČNE EVROPE
}

\section{COMPARATIVE ANALYSIS OF THE STARTUP ECOSYSTEM IN THE REPUBLIC OF SERBIA AND THE SOUTHEAST EUROPEAN COUNTRIES}

\author{
Kristina Janjić, Fakultet tehničkih nauka, Novi Sad
}

\section{Oblast - INOVACIJE I PREDUZETNIŠTVO}

Kratak sadržaj - Rad se bavi analizom i predstavljanjem startapa u Republici Srbiji. Opisano je stanje startap ekosistema u državi kao i poređenje sa drugim državama Jugoistočne Evrope i njihovim ekosistemima. Predstavljeni su uspešni domaći startapi koji su prepoznati $u$ svetu. Analizirani su načini finansiranja i podrške startapima.

Ključne reči: startap, preduzetnički ekosistem, finansiranje Abstract - The paper deals with the analysis and presentation of startups in the Republic of Serbia. The state of the startup ecosystem in the country is described, as well as a comparison with other countries in Southeast Europe and their ecosystems. Successful domestic startups that are recognized in the world are presented. Ways of financing and supporting startups are analyzed.

Keywords: Startup, Entrepreneurial ecosystem, Financing

\section{UVOD}

Preduzetništvo i startapi (engl. start up) imaju sličnosti, ali ne podrazumevaju iste stvari. Preduzetništvo je termin koji se odnosi na sve nove biznise, uključujući i samozapošljavanje, kao i male biznise koji nemaju nameru da rastu u istoj meri kao i startapi [1].

Startapi su novi biznisi koji imaju nameru da rastu, brzo se razvijaju, da imaju zaposlene i brzo šire tim koji im pomaže da dostignu ambiciozne ciljeve.

Rezultati Startup Genome izveštaja predstavljaju odličnu osnovu za analizu startap ekosistema u Srbiji i okolini [2].

Zdrav preduzetnički ekosistem bi trebalo da imafunkciju efikasne alokacije resursa $i$, po pravilu, da sadrži tri ključne komponente: agente, institucije i sistem. Agenti su pojedinci, odnosno preduzetnici, koji donose uglavnom dobro promišljene odluke o upotrebi retkih resursa imajući u vidu brojna institucionalna ograničenja. Preduzetnike odlikuje težnja ka inovativnom poslovanju i spremnost za preduzimanje rizičnih poduhvata. Oni su zapravo inicijatori promena koje odstupaju od postojećeg institucionalnog okruženja. Svojom aktivnošću oni neminovno doprinose promenama strukture formalnih i neformalnih pravila igre.

\section{NAPOMENA:}

Ovaj rad proistekao je iz master rada čiji mentor je bila dr Jelena Borocki, red.prof.

\section{2. ŠTA JE STARTAP?}

Do sad je već postalo jasno da uopšte nije lako dati jednostavan odgovor na ovo pitanje, tako da se ovaj pojam ne može objasniti u jednoj rečenici. Najjednostavnije rečeno, startap je inovativan tehnološki biznis koji imapotencijal brzog rasta $\mathrm{i}$ velikih dometa. Brzi rast $\mathrm{i}$ veliki dometi znače da taj biznis ima potencijal da od ideje do tržišne vrednosti od nekolika miliona eura (pa do npr. nekoliko milijardi) dođe za 5-7 godina [3].

„Startap je institucija sačinjena od ljudi, dizajnirana da isporuči novi proizvod ili uslugu u uslovima gdje je dosta stvari nepoznato [4]."

Termin startap je poreklom iz engleskog jezika, postao je popularan nakon osnivanja velikog broja dot-com kompanija na zapadu. Sama reč znači pokrenuti ili započeti. Startap su uglavnom novostvorene kompanije, odnosno početnici u poslovanju, a startap kredit i vrsta mikrokredita namenjenih za osnivanje ovih firmi.

\section{PREDUZETNIČKI EKOSISTEM}

Startap ekosistem Rep. Srbije je značajno porastao u poslednjih nekoliko godina, međutim, da bi bio razuman i još važnije, kvalitetno podržan, potrebno je pravilno ga sagledati.

Startapi predstavljaju jezgro inovacija i kreiranja novih proizvoda i usluga, međutim, oni sami ne bi mogli da opstanu bez ostalih ključnih komponenti koji se nalaze u njihovom okruženju. Startapi nastaju i razvijaju se u okruženju koje nazivamo startap ekosistem, koje okuplja ljude, startape u različitim fazama razvoja i različite tipove organizacija na lokaciji (fizičkoj ili virtuelnoj) koji interaguju međusobno s ciljem da nastanu nove startap kompanije.

Kada se govori o zrelosti ekosistema, prema procenama organizacije Startup Genome, srpski startap ekosistem nalazi se u svojoj ranoj razvojnoj fazi, poznatijoj kao faza Aktivacije. Trenutno je prisutno između 200 i 400 startapa u Beogradu i Novom Sadu (koji je u izveštaju definisan kao jedinstven preduzetnički ekosistem), što je u skladu sa prosekom za ovu fazu razvoja i slično je sa brojem startapa u gradovima u regionu kao što su Varšava i Bukurešt, dok jetaj broj duplo veći od broja startapa u Budimpešti.

Iako ekosistem Beograd i Novi Sad ima značajno niži BDP, najmanji broj IT stručnjaka na 1.000 stanovnika ipak uspeva da održi korak sa iznosom investicija, brojem startapa i akvizicija [5]. 


\section{STARTAPI U REPUBLICI SRBIJI I NJIHOVI OSNIVAČI}

Najperspektivniji startapi u R.Srbiji su blockchain i razvoj video igara (gaming). Pored toga, domaći startapi se u velikoj meri značajno bave i kreiranjem rešenja za velike kompanije,proizvodima koji koriste veštačku inteligenciju i rad sa velikom količinom podataka (Big Data), kao i pametnim gradovima.

U pogledu odgovarajuće startap podrške, Beograd je najrazvijeniji, ali mnogi drugi gradovi uspevaju da održe korak kroz aktivnosti javnog i privatnog sektora.Beograd od 2015. godine ima Naučno-tehnološki park, dok je Naučno-tehnološki park u Nišu i Novom Sadu od skoro u funkciji. Iako brojni gradovi širom zemlje imaju svoje poslovne inkubatore, samo su oni iz Novog Sada i Beograda, većinom, usmereni na tehnološki biznis. Beograd ima tri haba, Novi Sad ima samo jedan, a više od 10 gradova u Srbiji ima svoje habove, koji takođe rade na nekim startap programima [6].

Beograd i Novi Sad zaostaju za globalnim prosekom kada govorimo o lokalnoj povezanosti. Analiza otkriva da je način na koji osnivači i investitori pomažu jedni drugima (osećaj zajedništva) i broj kvalitetnih veza među osnivačima, kao i veza osnivača sa investitorima i ekspertima (lokalne veze), ispod globalnog nivoa.

\section{FINANSIRANJE STARTAPA}

Finansiranje startapa obično postane deo razgovora u široj javnosti samo kada se pojavi velika investicija ili akvizicija. Ovo se delom dešava zbog činjenice da su ovakve situacije više izuzetak nego pravilo u startap ekosistemu Srbije. Štaviše, vrlo često osnivači startapa vole da informacije o investicijama drže „,ispod radara“ i daleko od očiju javnosti.

\subsection{Podrška države za finansiranje}

Svake godine Ministarstvo ekonomije i regionalnog razvoja Srbije raspisuje konkurs za odobravanje kredita za početnike preduzetnike bez hipoteka i startap kredite za pravna lica. Oni se plasiraju preko Fonda za razvoj, a uključena je i Republička Agencija za razvoj malih i srednjih preduzeća sa mrežom centara i kancelarija čime se pruža podrška početnicima.

\subsection{Načini finansiranja}

Trenutno, u Srbiji ima samo nekoliko opcija putem kojih startapi mogu dobiti eksterno finansiranje iuglavnom su usmereni ka startapima u ranoj fazi.To su:

Fond za inovacionu delatnost, SC Ventures, ICT Hub Ventures, Startlabs.

\section{PREDNOSTI I SLABOSTI STARTAPA}

Velika prepreka za lokalne startape leži u činjenici da sumogućnosti digitalizacije finansijskih transakcija $u$ Srbiji prilično ograničene, pre svega zbog Zakona o deviznom poslovanju (ZDP) i njegove restriktivnosti $u$ oblasti međunarodnih transakcija. U kontekstu inovacija domaće ekonomije, pravna nesigurnost uvodi se principom ovog zakona da je sve što nije dozvoljeno zabranjeno, što je $u$ suprotnosti sa neprestanim promenama $u$ poslovnom svetu, posebno u kontekstu razvoj digitalne ekonomije.

\subsection{Srbija u poređenju sa Centralnom i Istočnom Evropom}

U odnosu na svoju veličinu i broj stanovnika, Srbija ima natprosečan broj startapa u poređenju sa vršnjacima iz faze Aktivacije, dok su nedavne velike tehnološke akvizicije pokazale potencijal ekosistema.

Osim što su prepoznati kao lideri u regionu, Bukurešt, Varšava i Budimpešta imaju sličnu populaciju kao Beograd i Novi Sad zajedno, zbog čega su izabrani za poređenje.

Slika 1- Broj startapa [7]

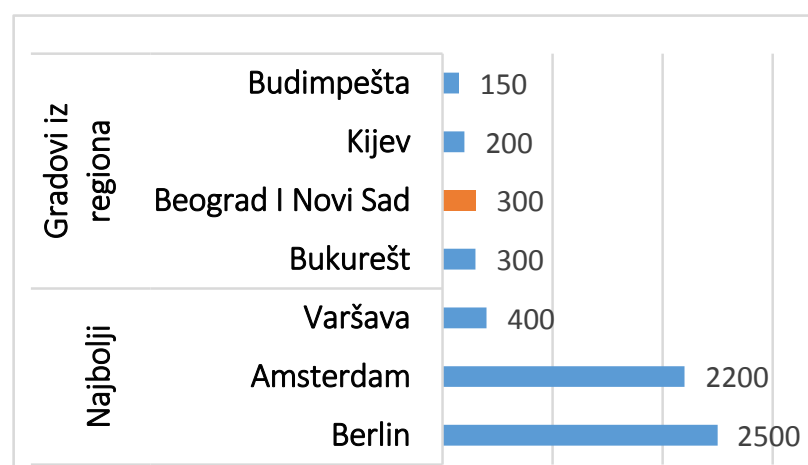

Zanimljivo je da je za sve ove gradove gustina startapa (koliko ima startapa po glavi stanovnika) iznad proseka u odnosu na druge ekosisteme u fazi Aktivacije. To znači da oni već posluju iznad svojih kapaciteta i da bi morali da urade više kako bi prešli u narednufazu.

Kijev, poznat kao vrlo popularna outsourcing destinacija, uveliko zaostaje u broju startapa, posebno ako uzmemo u obzir da je skoro duplo veći od ostalih ekosistema koje smo merili.

Slika 2 - Iznos investicija prikupljenih od strane srpskih startapa u poređenju sa drugima iz centralne i istočne Evrope (od 2013. godine, u milionima $€$ ).

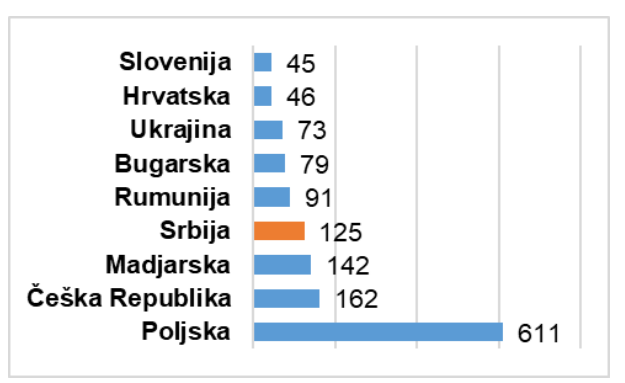

Kada se poredi u odnosu na broj stanovnika, R. Srbija ima najniži broj stanovnika u odnosu na prvih 5 zemalja i najniži BDP od svih zemalja na listi, a 5 i 3 puta niži od onih u Češkoj i Mađarskoj. Ovo je posebno važno ako se u obzir uzme da je Srbija, do sada, imala jednu od najnižih institucionalnih podrški prema finansiranju startapa.

\section{Uporedna analiza startap ekosistema država Jugoistočne Evrope}

Prvi uvid iz analize jeste da u svakoj zemlji u regionu postoji startap zajednica i bar neki osnovni ekosistem za podršku startapu. Postoje jasne razlike između zemalja, ali nijedna zemlja nije potpuno bez ekosistema. 
Tabela 1. Uporedna analiza startap ekosistema u državama Jugoistočne Evrope

\begin{tabular}{|c|c|c|c|c|c|}
\hline Država & $\begin{array}{c}\text { Broj } \\
\text { startapa }\end{array}$ & Popularne industrije & Investitori & $\begin{array}{c}\text { Broj } \\
\text { akceleratora/ } \\
\text { inkubatora } \\
\end{array}$ & $\begin{array}{c}\text { Prikupljeni } \\
\text { kapital } \\
(2016 . g o d)\end{array}$ \\
\hline Albanija & 160 & IKT, Trgovina, Putovanja & Yunus Social Business & 4 & $<$ USD1 mil \\
\hline $\mathbf{B i H}$ & 179 & $\begin{array}{c}\text { Trgovina, Obrazovanje, } \\
\text { IKT }\end{array}$ & $\begin{array}{c}\text { Foundation Networks, } \\
\text { Mozaik }\end{array}$ & 6 & $<$ USD1mil \\
\hline Hrvatska & 500 & $\begin{array}{c}\text { Automobilska industrija, } \\
\text { poljoprivreda, kiber- } \\
\text { netička sigurnost i } \\
\text { telekomunikacije. }\end{array}$ & $\begin{array}{c}\text { South Central Ventures, } \\
\text { CRANE }\end{array}$ & 8 & USD $15 \mathrm{mil}$ \\
\hline Crna Gora & 59 & $\begin{array}{c}\text { Turizam, Sport, Video } \\
\text { igre }\end{array}$ & l & 1 & $<$ USD1mil \\
\hline R.Srbija & 631 & $\begin{array}{c}\text { Software and Data, } \\
\text { Socijalna i razonoda, } \\
\text { e-trgovina i maloprodaja }\end{array}$ & $\begin{array}{l}\text { VC (venture capital) } \\
\text { fond, Biznis anđeli, } \\
\text { državne pozajmice }\end{array}$ & 25 & USD1-5mil \\
\hline Slovenija & 439 & $\begin{array}{l}\text { Software and Data, } \\
\text { Socijalnairazonoda, } \\
\text { e-trgovina i maloprodaja }\end{array}$ & $\begin{array}{l}\text { Slovenački poslovni } \\
\text { anđeli, RSG Kapital, } \\
\text { STH VC Fund, ABC } \\
\text { First Growth, Silicon } \\
\text { Gardens Fund, Fil Rouge } \\
\text { Capital } \\
\end{array}$ & 20 & USD 95mil \\
\hline
\end{tabular}

\section{STARTAP USPEŠNE PRIČE R. SRBIJE}

Srbija je uvek bila plodno tlo za inovacije. Na žalost, mnogi ljudi još uvek ne znaju da su neki od najvećih izumitelja na svetu bili Srbi; dovoljno je spomenuti Nikolu Teslu ili Mihajla Pupina.

Prošle godine je Srbija prvi put uključena u istraživanje Startup Genome-a, gde se može pročitati da postoji između 200 i 400 startupa, a vrednost ekosistema je skoro 300 miliona evra [8].

U poslednjoj dekadi pojavili su se brojni startapi koji su dokazali da je moguće dostići globalni uspeh iz Srbije. U nastavku je lista onih koji su imali veći uspeh, i koji kontinuirano doprinose ekosistemu: FitPass, Fshing Booker, Blinking, Nordeus, Visaris, activeColla.

\section{UTICAJ COVID-19 NA STARTAP}

Svi identifikovani rizici i prilike iznedrili su potrebu za novim $\mathrm{i}$ inovativnim digitalnim rešenjima $\mathrm{u}$ novom ekosistemu koji je nastao preko noći.

Pored činjenice da neće sve kompanije pretrpeti negativne posledice ove pandemije, potrebno je istaći i da je više od polovine Fortune 500 kompanija nastalo u periodima kriza.

Dodatno, važno je napomenuti da su nakon ekonomske krize 2007-2009. godine tehnološke kompanije te koje su se brže oporavile od ostatka privrede.

Kako ova kriza utiče na domaću digitalnu privredu naročito je važno ako se zna da je ona u poslednjem periodu beležila nemali rast. Rekordni prošlogodišnji izvoz iznosio je 1,4 milijarde evra, dok su Beograd i Novi Sad prepoznati u izveštaju Startup Genome-a kao relevantni za razvoj startapa, posebno u domenu razvoja video-igara i blockchain-a.

\section{ZAKLJUČAK}

Analiza regionalne perspektive kroz nekoliko kriterijuma jasno je pokazala da srpski startap ekosistem deluje bolje nego što se očekivalo. Ima daleko najniži BDP i broj IT stručnjaka na 1.000 ljudi, ali ide u korak sa investicijama, brojem startapa i akvizicija. Međutim, budući da je ekosistem u ranoj fazi, ovaj dobar početak može se lako izgubiti ako se ne pruži značajnija podrška našim startapima.

Jedna od velikih prepreka lokalnog ekosistema je nizak nivo finansiranja u ranoj fazi - u Beogradu i Novom Sadu veličina investicija u ranoj fazi (seed) je 90\% niža u odnosu na svetski prosek za ekosisteme koji su u fazi aktivacije.

Stoga, ključno je da Vlada napravi programe podrške kojim bi se povećalo finansiranje ustartape. Najznačajniji program u ovom deluje kroz Inovacioni fond. Ova bespovratna sredstva su glavni izvor finansiranja za lokalne startape, ali da bi ekosistem nastavio a raste, moraju se kreirati dodatni mehanizmi podrške investiranju.

\section{LITERATURA}

[1] https://belgrade.impacthub.net/startap_vs_biznis/

[2] https://startupgenome.com/report/gser2020 (pristupljeno u septembru 2020.)

[3] https://digitalizuj.me/2015/12/sta-je-to-startup/ (pristupljeno u septembru 2020.)

[4] E.Ries, The Lean Startup, USA, 2011

[5] https://startupgenome.com/report/gser2020 (pristupljeno u septembru 2020.)

[6] T.Kuzman, Z.Kukić, A.Kovač, Startap skener 2019, Inicijativa Digitalna Srbija, 2019

[7] https://www.luxinnovation.lu/tradeandinvest/wpcontent/uploads/sites/3/2018/05/nexten_software de 
velopers_study_europe.pdf (pristupljeno u septembru 2020.)

[8] https://www.eu-startups.com/2020/05/serbiasstartup-ecosystem-at-a-glance/(pristupljeno u septembru 2020.)

\section{Kratka biografija:}

Kristina Janjić rođena u Užicu 1995. godine. Diplomski rad na Fakultetu tehničkih nauka iz oblasti Inženjerski menađžment, modul Inovacije i preduzetništvo odbranila je 2019. godine. 